\title{
PRODUCTION OF TOMATO SEEDLINGS USING DIFFERENT SUBSTRATES AND TRAYS IN THREE PROTECTED ENVIRONMENTS
}

\author{
EDILSON COSTA ${ }^{1}$, PAULO A. M. LEAL ${ }^{2}$, CLEITON G. S. BENETT ${ }^{3}$, \\ KATIANE S. S. BENETT ${ }^{4}$, LUIZ C. P. SALAMENE ${ }^{5}$
}

\begin{abstract}
The seedlings production is an essential part for vegetables production. Thus, this study aimed to evaluate the environment, the substrates and the containers in the development of tomato seedlings, cv. Santa crus Kada Gigante, in Aquidauana -MS, Brazil region, from October to November, 2008. Polystyrene trays with 72; 128 and 200 cells, filled with four substrates (soil; Plantmax ${ }^{\circledR}$; coconut fiber and vermiculite) were tested in three protected environments (greenhouse; screened with Sombrite ${ }^{\circledR}$ and screened with Aluminet ${ }^{\circledR}$ ). The experimental design was completely randomized, factorial scheme $3 \times 4$ (three trays $\mathrm{x}$ four substrates), with four replications, being analyzed individual variance analysis and joint analysis for the environments. The environment with screens (Sombrite ${ }^{\circledR}$ and Aluminet ${ }^{\circledR}$ ), the trays with 72 cells and the vermiculite produced better results.
\end{abstract}

KEYWORDS: Solanum lycopersicum, protected cultivation, propagation.

\section{PRODUÇÃO DE MUDAS DE TOMATE USANDO-SE DIFERENTES SUBSTRATOS E TIPOS DE BANDEJAS EM TRÊS AMBIENTES PROTEGIDOS}

RESUMO: A produção de mudas é uma etapa essencial na cadeia produtiva de hortaliças. Desta forma, este trabalho teve os objetivos de avaliar a ambiência, os substratos e os recipientes no desenvolvimento de mudas de tomateiro, cv. Santa Cruz Kada Gigante, na região de AquidauanaMS, de outubro a novembro de 2008. Foram testadas bandejas de poliestireno com 72; 128 e 200 células, preenchidas com quatro substratos: solo; Plantmax ${ }^{\circledR}$; fibra de coco fina, e vermiculita, em três ambientes protegidos: estufa, telado com Sombrite ${ }^{\circledR}$ e telado com Aluminet ${ }^{\circledR}$. O experimento foi conduzido em delineamento inteiramente casualizado, em esquema fatorial 3 x 4 (três bandejas x quatro substratos), com quatro repetições, realizando-se de análises de variâncias individuais e análise conjunta dos ambientes. Os ambientes telados (Sombrite ${ }^{\circledR}$ e Aluminet ${ }^{\circledR}$ ), a bandeja com 72 células e a vermiculita produziram as melhores mudas.

PALAVRAS-CHAVE: Solanum lycopersicum, cultivo protegido, propagação.

\section{INTRODUCTION}

The tomato (Solanum lycopersicum), very important vegetable in the Brazilian consumer diet, is cultivated for consumption innatura and for industrial processing. In Midwest region of Brazil, the state of Goiás is the main producer with $95.72 \%$, which represents $33.11 \%$ of national production (IBGE, 2010). Because of the small production and the increasing consumption, the state of Mato Grosso do Sul cannot supply its vegetable market, so imports about $85 \%$ of the consumed products, mainly from the states of São Paulo and Paraná (BOLETIM ANNUAL, 2011). By the same reference it is verified that, among the vegetables consumed in Mato Grosso do Sul, the tomato corresponds to $13.5 \%$.

\footnotetext{
${ }^{1}$ Prof. Dr., Universidade Estadual de Mato Grosso do Sul - UEMS, Unidade Universitária de Cassilândia, Cassilândia - MS, mestrine@uems.br.

${ }^{2}$ Eng ${ }^{\mathbf{0}}$ Agrícola, Prof. Titular, FEAGRI/UNICAMP, Campinas - SP, pamleal@ feagri.unicamp.br.

${ }^{3}$ Dr., Bolsista DCR (Desenvolvimento Científico e Tecnológico Regional), FAPEG/CNPq, Goiânia-GO, cbenett@hotmail.com.

${ }^{4}$ Profa. Dra., Universidade Estadual de Goiás - UEG, Ipameri - GO, kasantiago@ig.com.br.

${ }^{5}$ Eng $^{\mathrm{o}}$ Agrônomo, Mestrando em Produção Vegetal, Agronomia/UEMS/Aquidauana, luizcarlos@uems.br.

Recebido pelo Conselho Editorial em: 29-6-2011
}

Aprovado pelo Conselho Editorial em: 27-5-2012 
The tomato reaches productivity of $104.79 \mathrm{t} \mathrm{ha}^{-1}$ in field or in protected environment, where it is used perforated bags of $9.0 \mathrm{~L}$, filled with $75 \%$ of sand and $25 \%$ of organic compound and fertirrigated by dripping (FONTES et al., 2004). CARRIJO et al. (2004) state that the production in protected environment is easier to manage than in field.

The best productions are achieved with seedlings of quality. Thus, the seedling production requires technologies, such as new substrates and containers that provide healthy and vigorous plants for the formation of seedbeds (RODRIGUES et al., 2010).

The plant environment is the study of the climatic elements of the production area, allowing using better alternatives of environment management for the plants development. Its knowledge is important for the appropriateness of the production in protected environments, like greenhouses, nurseries and acclimatized greenhouses. COSTA et al. (2009a) and COSTA et al. (2010) with cucumber and COSTA et al. (2011) with eggplant, have been performing studies that evaluate the vegetable environment in seedling formation of high quality vegetables.

This study aimed to evaluate the environment, substrates and containers in tomato seedling development in region of Aquidauana - MS, Brazil.

\section{MATERIAL AND METHODS}

It was used the tomato (Solanum lycopersicum), cv. Santa Cruz Kada Gigante, with seedling production in different substrates and in expanded polystyrene trays and protected environments, from October to November, 2008, in the State University of Mato Grosso do Sul, University Unit of Aquidauana, that is located in the Altitude $147 \mathrm{~m}$, Latitude $-20^{\circ} 28^{\prime} 16^{\prime}$ ' and Longitude $-55^{\circ} 47^{\prime} 14^{\prime \prime}$. The region climate, according to the Köeppen classification, is Aw, defined as humid tropical climate and the annual average temperature is $29{ }^{\circ} \mathrm{C}$.

Three cultivation environment were tested: greenhouse in arch, with galvanized steel structure ( $8.00 \mathrm{~m} \times 18.00 \mathrm{~m} \times 4,00 \mathrm{~m})$, zenithal ventilation, covered by low density polyethylene film (LDPF) of 150 um, light diffuser, thermo-reflective screen with 50\% shading, closures in the front and side with monofilament screen with $50 \%$ shading; nursery of galvanized steel $(8.00 \mathrm{~m} \mathrm{x}$

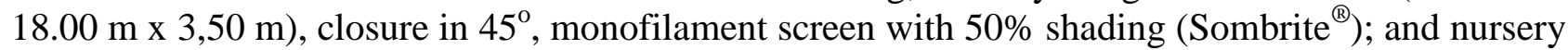
of galvanized steel $(8.00 \mathrm{~m} \times 18.00 \mathrm{~m} \times 3.5 \mathrm{~m})$, closure in $45^{\circ}$ with thermo-reflective screen with $50 \%$ shading (Aluminet ${ }^{\circledR}$ ). The environments were differentiated by the kind of material in the covering and in the side: greenhouse covered with LDPF and Aluminet ${ }^{\circledR}$ screen and sides with Sombrite $^{\circledR}$; screenhouse of monofilament with covering and sides of Sombrite ${ }^{\circledR}$ and the thermoreflective screen with covering and sides of Aluminet ${ }^{\circledR}$.

In each cultivation environment the seedling production was tested in three containers or polystyrene trays with 72 cells, with dimension $5.0 \mathrm{~cm} \times 12.0 \mathrm{~cm}$ and size of $121.2 \mathrm{~cm}^{3} ; 128$ cells, with dimension $3.5 \mathrm{~cm} \times 6.2 \mathrm{~cm}$ and size of $34.6 \mathrm{~cm}^{3}$; and 200 cells, with dimension $2.8 \mathrm{~cm} \mathrm{x}$ $6.0 \mathrm{~cm}$ and size of $22.3 \mathrm{~cm}^{3}$. They were filled with four substrates: soil, Plantmax ${ }^{\circledR}$, fine coconut fiber and vermiculite. The coconut fiber was Golden Mix $47^{\circledR}$ (Coconut Fiber of fine texture, $H T$ hortaliças), the Plantmax ${ }^{\circledR}$ was HT hortaliças and the vermiculite of medium texture.

All substrates were fertilized with the organic compound Organosuper ${ }^{\circledR}, 15 \%$ of volume and dosages of $2.5 \mathrm{~kg}$ of simple superphosphate $\left(\mathrm{P}_{2} \mathrm{O}_{5}\right), 0.3 \mathrm{~kg}$ of potassium chloride $(\mathrm{KCl})$ and $1.5 \mathrm{~kg}$ of dolomitic limestone filler (PRTN-100\% pure), per meter cubic. Nitrogen was not applied considering that there was a fraction of the content in the organic compound.

The soil was taken from the area of the Aquidauana - Campus, in a layer of 10 to $40 \mathrm{~cm}$, which chemical analysis in presented in Table 1. The Organosuper ${ }^{\circledR}$ presents the following characteristics, according to the Embrapa Agropecuária Oeste Laboratory, Dourados, MS: $\mathrm{pH}=6.51 ;$ organic carbon $=26.2 \% ;$ humidity $=4.56 \% ;$ Nitrogen $=1.83 \% ;$ Phosphorus $=0.96 \%$; Potassium $=0.35 \% ;$ Calcium $=6.24 \% ;$ Magnesium $=0.88 \% ;$ Sodium $=0.23 \%$. 
The experiments with containers and substrates were conducted in a completely randomized design (CRD), in a factorial scheme $3 \times 4$ (three trays $\mathrm{x}$ four substrates), with four replications, in average four seedlings in each repetition. The results were submitted to individual variance analysis of containers $\mathrm{x}$ substrates, in each cultivation environment. Following it was performed the evaluation of the mean squares of residues (BANZATTO \& KRONKA, 2006) and the joint analysis of the environments. The analysis were round in the statistic program Sisvar 5.3 (FERREIRA, 2010), and compared by the Tukey test $(\mathrm{p}<0.05)$.

The relative humidity of the environments was daily measured by dry and wet bulb thermometers, with reading at $9 \mathrm{am}, 12$ am and $15 \mathrm{am}$, from November $3^{\text {rd }}$ to November $20^{\text {th }} 2008$. The relative humidity was calculated using the Psychrometric Function Demo software (Table 1). For the temperature collects was used an analogical thermohygrometer, dry and wet bulb $\left(\right.$ INCOTERM $\left.^{\circledR}\right)$, in the center of the cultivation stand, in $1.0 \mathrm{~m}$ high from the soil.

TABLE 1. Chemical analysis of soil (S) and environmental variables, dry bulb temperature (DBT, ${ }^{\circ} \mathrm{C}$ ), wet bulb temperature (WBT, ${ }^{\circ} \mathrm{C}$ ) and average of relative air humidity $(\mathrm{RH}, \%)$ for each environment (A) of cultivation. Aquidauana-MS, Brazil, 2008.

\begin{tabular}{|c|c|c|c|c|c|c|c|c|c|}
\hline & $\mathrm{pH}$ & O.M. & $\mathrm{K}$ & $\mathrm{Ca}$ & $\mathrm{Mg}$ & $\mathrm{H}+\mathrm{Al}$ & SB & CTC & $\mathrm{V}$ \\
\hline & & $\%$ & & \multicolumn{4}{|c|}{$\mathrm{cmol}_{\mathrm{c}} \mathrm{dm}^{-3}$} & & $\%$ \\
\hline & 5.4 & 1.4 & 0.4 & 0.9 & 0.8 & 3.3 & 2.1 & 5.4 & 38.9 \\
\hline & \multicolumn{2}{|c|}{$09 \mathrm{H}$} & \multicolumn{2}{|c|}{$12 \mathrm{H}$} & \multicolumn{2}{|c|}{$15 \mathrm{H}$} & $09 \mathrm{H}$ & $12 \mathrm{H}$ & $15 \mathrm{H}$ \\
\hline & DBT & WBT & DBT & WBT & DBT & WBT & & RH & \\
\hline Greenhouse & 27.6 & 23.5 & 31.8 & 24.9 & 31.9 & 25.4 & 72.1 & 58.5 & 60.8 \\
\hline Sombrite $^{\circledR}$ & 27.1 & 23.8 & 31.8 & 25.0 & 32.3 & 25.7 & 75.8 & 59.0 & 60.6 \\
\hline Aluminet ${ }^{\circledR}$ & 27.3 & 24.0 & 32.6 & 26.0 & 32.8 & 26.3 & 77.5 & 60.8 & 61.9 \\
\hline
\end{tabular}

The sowing occurred in 10/21/2008, by putting two seeds per cell. The seedlings emergence started in 10/24/2008, with thinning in 10/30/2008, nine days after sowing (DAS), remaining one plant per container. The Irrigation was manual, by watering can.

The seedlings height $(\mathrm{SH})$ was measured in the $9^{\text {th }}, 14^{\text {th }}, 19^{\text {th }}, 24^{\text {th }}$ and $30^{\text {th }}$ day, after sowing. The data was submitted to regression analysis in function of time. In the 30th DAS the stem diameter (SD), aerial dry phytomass (ADP), dry root phytomass (DRP) and the total dry phytomass (TDP) were also measured in order to determine the Dickson quality index (DQI), through the equation: $\mathrm{DQI}=\mathrm{TDP} /(\mathrm{SH} / \mathrm{SD}+\mathrm{ADP} / \mathrm{DRP})$.

\section{RESULTS AND DISCUSSION}

Except the Dickson quality index, for all of the evaluated variables the relation between the mean square of the individual variance analysis residues did not surpass the relation 7:1 (Table 2), allowing the joint analysis of the experiments (BANZATTO \& KRONKA, 2006) and the comparison of the protected environments.

TABLE 2. Mean square of the individual analysis for plant height ( $\mathrm{Ph}$ ), stem diameter (SD), aerial dry phytomass (ADP), dry root phytomass (DRP), total dry phytomass (TDP) and Dickson quality index (DQI) of "Santa Cruz Kada Gigante" tomato seedlings, 30 days after sowing. Aquidauana - MS, 2008.

\begin{tabular}{lcccccc}
\hline & \multicolumn{6}{c}{ Mean Square of the Individual Analysis Residues (MSR) } \\
\hline & $\mathrm{Ph}$ & $\mathrm{SD}$ & ADP & DRP & TDP & DQI \\
\hline Grenhouse & 0.0078 & 0.0015 & 0.000003 & $1.17 \mathrm{E}-07$ & 0.000003 & $2.10 \mathrm{E}-08$ \\
Sombrite $^{\circledR}$ & 0.0310 & 0.0038 & 0.000008 & $1.64 \mathrm{E}-07$ & 0.000009 & $1.64 \mathrm{E}-07$ \\
Aluninet $^{\circledR}$ & 0.0085 & 0.0019 & 0.000005 & $5.16 \mathrm{E}-07$ & 0.000006 & $1.70 \mathrm{E}-07$ \\
\hline RMSR $^{*}$ & 4.0 & 2.5 & 2.7 & 4.4 & 3.0 & 8.1 \\
\hline
\end{tabular}

*RMSR = relation between the highest and the lowest mean square of the individual analysis residues in the cultivation environment. 
The results presented in Tables 3; 4 and 5 indicate interactions among the studied factors (cultivation environment, type of tray and substrate), showing that there is an interference of the cell volume and the substrate in growing and formation of tomato seedlings, as well as cultivation environments.

TABLE 3. Interactions between environments and containers for seedlings height, stem diameter, aerial dry phytomass, dry root phytomass and total dry phytomass of tomato seedlings evaluated 30 days after sowing. Aquidauana - MS, Brazil, 2008.

\begin{tabular}{|c|c|c|c|c|c|c|}
\hline & \multicolumn{3}{|c|}{ Seedlings Height (cm) } & \multicolumn{3}{|c|}{ Stem Diameter (mm) } \\
\hline Cells & Greenhouse & Sombrite $^{(\mathbb{B}}$ & Aluminet $^{\circledR}$ & Greenhouse & Sombrite $^{\circledR}$ & Aluminet $^{\circledR}$ \\
\hline 72 & $4.5 \mathrm{Ac}^{*}$ & $5.7 \mathrm{Aa}$ & $4.9 \mathrm{Ab}$ & $1.35 \mathrm{Aa}$ & $1.32 \mathrm{Aa}$ & $1.33 \mathrm{Aa}$ \\
\hline 128 & 4.1 Bc & $5.0 \mathrm{Ba}$ & 4.7 Bb & $1.19 \mathrm{Ba}$ & $1.15 \mathrm{Ba}$ & $1.17 \mathrm{Ba}$ \\
\hline 200 & $4.0 \mathrm{Cb}$ & 4.2 Ca & $4.2 \mathrm{Ca}$ & $1.00 \mathrm{Cb}$ & $0.86 \mathrm{Cc}$ & $1.09 \mathrm{Ca}$ \\
\hline & \multicolumn{3}{|c|}{ Aerial dry phytomass (g) } & \multicolumn{3}{|c|}{ Dry root phytomass $(\mathrm{g})$} \\
\hline 72 & $0.036 \mathrm{Ab}$ & $0.051 \mathrm{Aa}$ & $0.051 \mathrm{Aa}$ & $0.0101 \mathrm{Aa}$ & $0.0102 \mathrm{Aa}$ & $0.0083 \mathrm{Ab}$ \\
\hline 128 & $0.021 \mathrm{Bc}$ & $0.030 \mathrm{Bb}$ & $0.038 \mathrm{Ba}$ & $0.0074 \mathrm{Bab}$ & $0.0078 \mathrm{Ba}$ & $0.0071 \mathrm{Bb}$ \\
\hline 200 & $0.016 \mathrm{Cb}$ & $0.018 \mathrm{Ca}$ & $0.019 \mathrm{Ca}$ & $0.0028 \mathrm{Cc}$ & $0.0054 \mathrm{Ca}$ & $0.0038 \mathrm{Cb}$ \\
\hline & \multicolumn{3}{|c|}{ Total dry phytomass $(\mathrm{g})$} & & - & \\
\hline 72 & $0.046 \mathrm{Ab}$ & $0.062 \mathrm{Aa}$ & $0.060 \mathrm{Aa}$ & - & - & - \\
\hline 128 & $0.029 \mathrm{Bc}$ & $0.038 \mathrm{Bb}$ & $0.045 \mathrm{Ba}$ & - & - & - \\
\hline 200 & $0.018 \mathrm{Cb}$ & $0.024 \mathrm{Ca}$ & $0.023 \mathrm{Ca}$ & - & - & - \\
\hline
\end{tabular}

TABLE 4. Interactions between environments and substrates, containers and substrate for plant height, stem diameter, aerial dry phytomass, dry root phytomass and total dry phytomass of tomato seedlings evaluated 30 days after sowing. Aquidauana - MS, Brazil, 2008.

\begin{tabular}{|c|c|c|c|c|c|c|}
\hline & \multicolumn{6}{|c|}{ Seedlings Height $(\mathrm{cm})$} \\
\hline & Greenhouse & Sombrite $^{\circledR}$ & Aluminet $^{\circledR}$ & 72 cells & 128 cells & 200 cells \\
\hline Soil & $3.9 \mathrm{Cb}^{*}$ & $5.0 \mathrm{Ba}$ & $4.0 \mathrm{Cb}$ & $4.6 \mathrm{Ca}$ & $4.7 \mathrm{Ba}$ & $3.7 \mathrm{Db}$ \\
\hline Plantmax $^{\circledR}$ & 4.1 $\mathrm{Bb}$ & 4.7 Ca & 4.7 $\mathrm{Ba}$ & 4.7 $\mathrm{Ba}$ & $4.5 \mathrm{Cb}$ & 4.3 Bc \\
\hline Coconutfiber & $3.8 \mathrm{Cb}$ & 4.1 Da & $3.8 \mathrm{Db}$ & $3.8 \mathrm{Db}$ & 3.9 Dab & $4.0 \mathrm{Ca}$ \\
\hline \multirow[t]{2}{*}{ Vermiculite } & $4.9 \mathrm{Ac}$ & $6.3 \mathrm{Aa}$ & $5.9 \mathrm{Ab}$ & 7.1 Aa & $5.4 \mathrm{Ab}$ & $4.5 \mathrm{Ac}$ \\
\hline & \multicolumn{6}{|c|}{ Stem Diameter (mm) } \\
\hline Soil & $1.26 \mathrm{Ba}$ & $1.18 \mathrm{Bb}$ & $1.11 \mathrm{Cc}$ & $1.33 \mathrm{Ba}$ & $1.23 \mathrm{Bb}$ & $0.99 \mathrm{Bc}$ \\
\hline Plantmax $^{\circledR}$ & $1.12 \mathrm{Cb}$ & $1.16 \mathrm{Bb}$ & $1.28 \mathrm{Ba}$ & $1.33 \mathrm{Ba}$ & $1.16 \mathrm{Cb}$ & $1.07 \mathrm{Ac}$ \\
\hline Coconutfiber & $0.92 \mathrm{Da}$ & $0.82 \mathrm{Cb}$ & $0.85 \mathrm{Db}$ & $0.85 \mathrm{Cb}$ & $0.97 \mathrm{Da}$ & $0.78 \mathrm{Cc}$ \\
\hline \multirow[t]{2}{*}{ Vermiculite } & $1.41 \mathrm{Ab}$ & $1.30 \mathrm{Ac}$ & $1.55 \mathrm{Aa}$ & $1.84 \mathrm{Aa}$ & $1.34 \mathrm{Ab}$ & $1.09 \mathrm{Ac}$ \\
\hline & \multicolumn{6}{|c|}{ Aerial dry Phytomass (g) } \\
\hline Soil & $0.033 \mathrm{Ab}$ & $0.040 \mathrm{Ba}$ & $0.029 \mathrm{Cc}$ & $0.048 \mathrm{Ba}$ & $0.036 \mathrm{Bb}$ & $0.018 \mathrm{Bc}$ \\
\hline Plantmax $^{\circledR}$ & $0.022 \mathrm{Bc}$ & $0.029 \mathrm{Cb}$ & $0.036 \mathrm{Ba}$ & $0.033 \mathrm{Ca}$ & $0.032 \mathrm{Ca}$ & $0.021 \mathrm{Ab}$ \\
\hline Coconutfiber & $0.010 \mathrm{Ca}$ & $0.008 \mathrm{Da}$ & $0.010 \mathrm{Da}$ & $0.009 \mathrm{Da}$ & $0.010 \mathrm{Da}$ & $0.009 \mathrm{Ca}$ \\
\hline \multirow[t]{2}{*}{ Vermiculite } & $0.034 \mathrm{Ac}$ & $0.055 \mathrm{Ab}$ & $0.068 \mathrm{Aa}$ & $0.095 \mathrm{Aa}$ & $0.040 \mathrm{Ab}$ & $0.022 \mathrm{Ac}$ \\
\hline & \multicolumn{6}{|c|}{ Dry root Phytomass(g) } \\
\hline Soil & $0.0059 \mathrm{Cb}$ & $0.0066 \mathrm{Ca}$ & $0.0039 \mathrm{Cc}$ & $0.0066 \mathrm{Ca}$ & $0.0066 \mathrm{Ca}$ & $0.0032 \mathrm{Cb}$ \\
\hline Plantmax $^{\circledR}$ & $0.0065 \mathrm{Bb}$ & $0.0073 \mathrm{Ba}$ & $0.0066 \mathrm{Bb}$ & $0.0073 \mathrm{Bb}$ & $0.0084 \mathrm{Ba}$ & $0.0046 \mathrm{Bc}$ \\
\hline Coconutfiber & $0.0040 \mathrm{Da}$ & $0.0042 \mathrm{Da}$ & $0.0020 \mathrm{Db}$ & $0.0048 \mathrm{Da}$ & $0.0037 \mathrm{Db}$ & $0.0017 \mathrm{Dc}$ \\
\hline \multirow[t]{2}{*}{ Vermiculite } & $0.0107 \mathrm{Ab}$ & $0.0131 \mathrm{Aa}$ & $0.0132 \mathrm{Aa}$ & $0.0193 \mathrm{Aa}$ & $0.0112 \mathrm{Ab}$ & $0.0066 \mathrm{Ac}$ \\
\hline & \multicolumn{6}{|c|}{ Total dry Phytomass (g) } \\
\hline$\overline{\text { Soil }}$ & $0.038 \mathrm{Bb}$ & $0.046 \mathrm{Ba}$ & $0.033 \mathrm{Cc}$ & $0.055 \mathrm{Ba}$ & $0.042 \mathrm{Bb}$ & $0.021 \mathrm{Bc}$ \\
\hline Plantmax $^{\circledR}$ & $0.028 \mathrm{Cc}$ & $0.036 \mathrm{Cb}$ & $0.043 \mathrm{Ba}$ & $0.041 \mathrm{Ca}$ & $0.041 \mathrm{Ba}$ & $0.026 \mathrm{Ab}$ \\
\hline Coconutfiber & $0.014 \mathrm{Da}$ & $0.012 \mathrm{Da}$ & $0.012 \mathrm{Da}$ & $0.013 \mathrm{Dab}$ & $0.014 \mathrm{Ca}$ & $0.011 \mathrm{Cb}$ \\
\hline Vermiculite & $0.044 \mathrm{Ac}$ & $0.069 \mathrm{Ab}$ & $0.082 \mathrm{Aa}$ & $0.115 \mathrm{Aa}$ & $0.051 \mathrm{Ab}$ & $0.028 \mathrm{Ac}$ \\
\hline
\end{tabular}

*Results followed by equal letters, uppercase in columns and lowercase in rows do not differ by the Tukey Test (p>0.05). 
TABLE 5. Dickson quality index in interaction between substrates and containers.Aquidauana-MS, Brazil, 2008.

\begin{tabular}{|c|c|c|c|c|}
\hline \multicolumn{5}{|c|}{ Dickson Quality Index (DQI) } \\
\hline \multirow{5}{*}{ Greenhouse } & & 72 cells & 128 cells & 200 cells \\
\hline & Soil & $0.0076 \mathrm{Ba}^{*}$ & $0.0041 \mathrm{Cb}$ & $0.0016 \mathrm{Cc}$ \\
\hline & Plantmax $^{\circledR}$ & $0.0050 \mathrm{Ca}$ & $0.0049 \mathrm{Ba}$ & $0.0019 \mathrm{Bb}$ \\
\hline & Coconutfiber & $0.0030 \mathrm{Da}$ & $0.0024 \mathrm{Db}$ & $0.0009 \mathrm{Dc}$ \\
\hline & Vermiculite & $0.0103 \mathrm{Aa}$ & $0.0066 \mathrm{Ab}$ & $0.0033 \mathrm{Ac}$ \\
\hline \multirow{4}{*}{ Sombrite $^{\circledR}$} & Soil & $0.0058 \mathrm{Ba}$ & $0.0041 \mathrm{Cb}$ & $0.0033 \mathrm{Bc}$ \\
\hline & Plantmax $^{\circledR}$ & $0.0055 \mathrm{Ba}$ & $0.0051 \mathrm{Ba}$ & $0.0030 \mathrm{Bc}$ \\
\hline & Coconutfiber & $0.0018 \mathrm{Cb}$ & $0.0023 \mathrm{Da}$ & $0.0011 \mathrm{Cc}$ \\
\hline & Vermiculite & $0.0119 \mathrm{Aa}$ & $0.0065 \mathrm{Ab}$ & $0.0040 \mathrm{Ac}$ \\
\hline \multirow{4}{*}{ Aluminet $^{\circledR}$} & Soil & $0.0021 \mathrm{Cb}$ & $0.0055 \mathrm{Ba}$ & $0.0013 \mathrm{Bc}$ \\
\hline & Plantmax $^{\circledR}$ & $0.0041 \mathrm{Bb}$ & $0.0058 \mathrm{Ba}$ & $0.0040 \mathrm{Ab}$ \\
\hline & Coconutfiber & $0.0014 \mathrm{Da}$ & $0.0014 \mathrm{Ca}$ & $0.0011 \mathrm{Ba}$ \\
\hline & Vermiculite & $0.0169 \mathrm{Aa}$ & $0.0067 \mathrm{Ab}$ & $0.0039 \mathrm{Ac}$ \\
\hline
\end{tabular}

* Results followed by equal letters, uppercase in columns and lowercase in rows do not differ by the Tukey Test (p>0.05).

All environments, trays and substrates allowed uniform growth of seedlings, high determination coefficients $\left(\mathrm{R}^{2}\right)$ and linear increasing of seedling height in function to time (Figures 1,2 and 3). The nursery with monofilament screen (Sombrite ${ }^{\circledR}$ ), with 30 days, presented the highest seedlings, with $5.0 \mathrm{~cm}$. The seedlings in the thermo-reflective screenhouse, however, presented more uniform growth, with higher $\mathrm{R}^{2}$ (Figure 1). In the screenhouses was observed balanced growth during the experiment, and larger plants at the end of it (Figures 1 and 2), as well as higher phytomass and stem diameters (Tables 3 and 4). This happened because the screenhouse did not present LDPF in its coverings, allowing better heat exchange with external environment; it probably enabled the tomato development. Similar results were observed by COSTA et al. (2010) in the evaluation of cucumber.

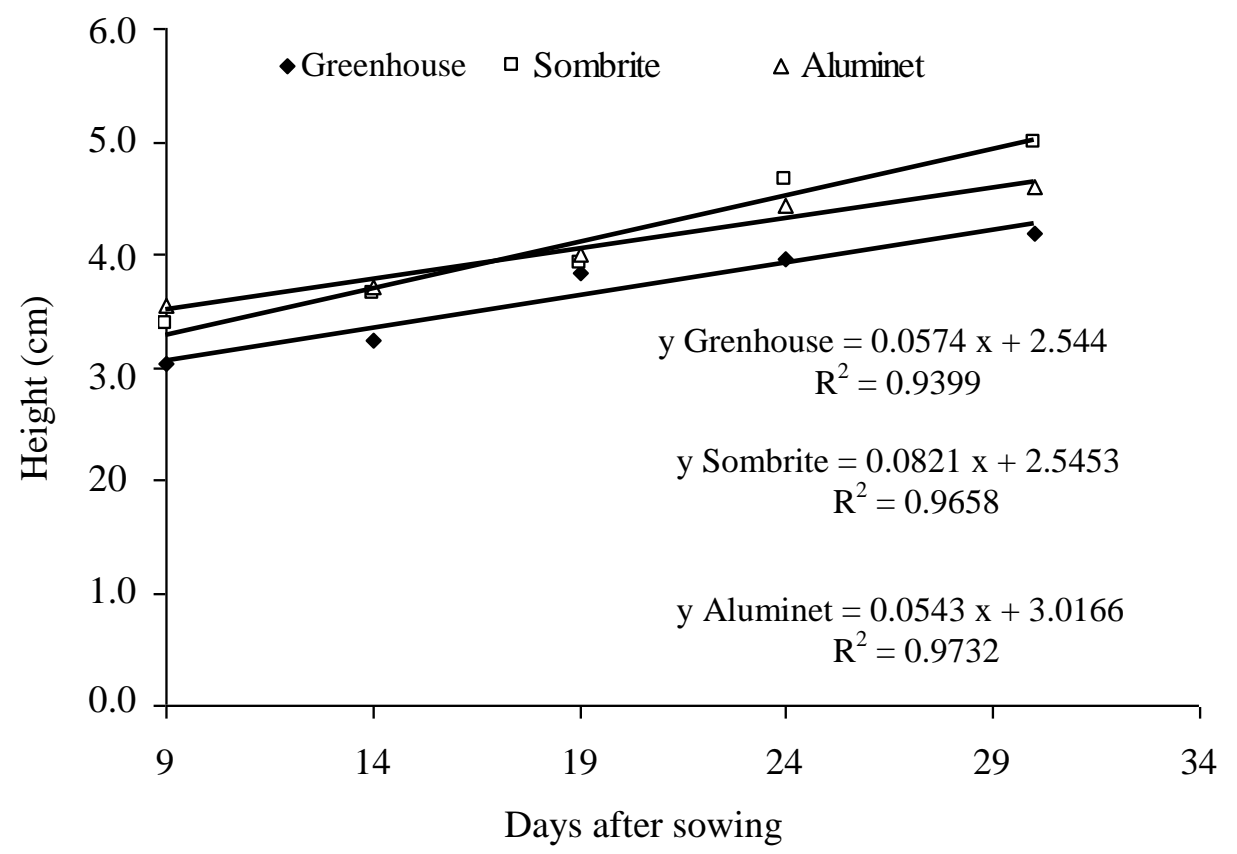

FIGURE 1. Tomato seedling Growth in different environments.Aquidauana - MS, Brazil, 2008. 


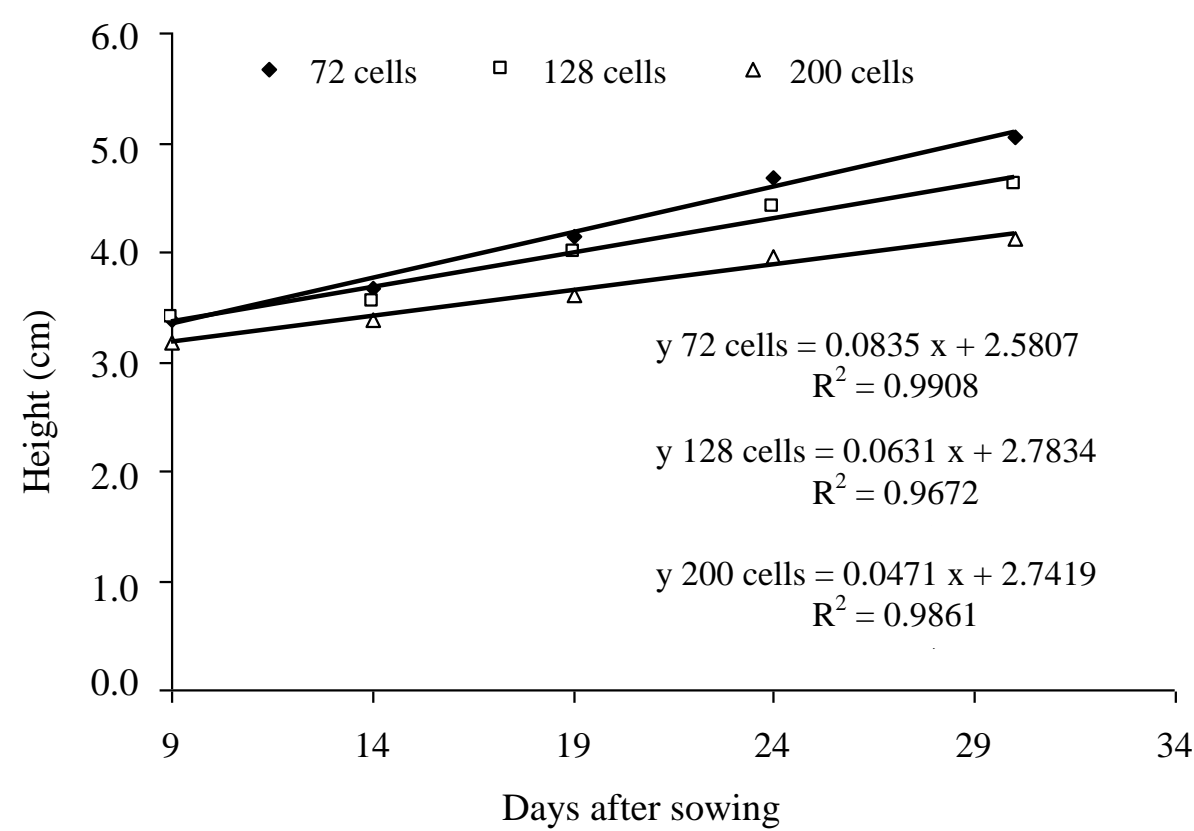

FIGURE 2. Tomato seedling growth in the different cultivation trays.Aquidauana - MS, Brazil, 2008.

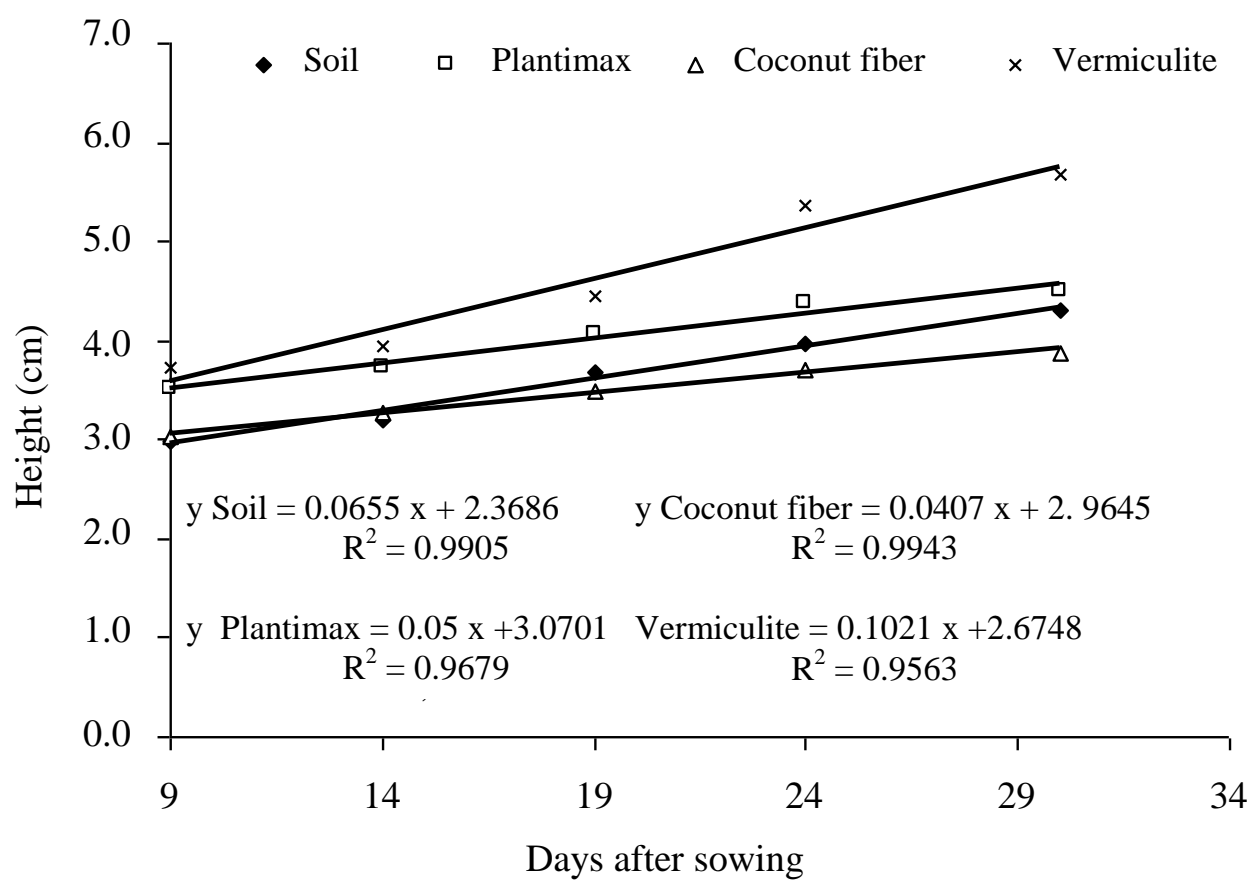

FIGURE 3. Tomato seedling growth in the different substrates.Aquidauana - MS, Brazil, 2008.

In the interactions between cultivation environments and type of tray were verified larger plants in the Sombrite ${ }^{\circledR}$, for all types of tray, and higher aerial dry phytomass in the screenhouses (Sombrite $^{\circledR}$ and Aluminet ${ }^{\circledR}$ ), for almost all the studied trays (Table 3). COSTA et al. (2010) also found higher dry root phytomass in hybrid plants of Nikkey and Safira cucumber (H3) cultivated in screen environments, if compared with greenhouses. In this study, the screen environments (Sombrite $^{\circledR}$ and Aluminet ${ }^{\circledR}$ ) allowed the rainwater entrance, what probably accelerated the organic matter degradation of the Organosuper ${ }^{\circledR}$ and provided larger quantity of nutrients for the plants, possibly by the $\mathrm{pH}$ reduction (VALENTE et al., 2009). 
The tray with higher volume (72 cells) provided better physical space conditions for the root development, and consequently larger seedlings with uniform growth, indicated by higher $\mathrm{R}^{2}$ (Figure 2).

In the vermiculite substrate, larger seedlings were observed (Figure3), because this material granted better porosity and water retention (LUZ et al., 2004). With the same material as substrate mean component, larger coffee trees seedlings were found by CUNHA et al. (2002).

The tray with higher cell volume presented the best seedlings, for all the cultivation environments (Table 3). Depending on the substrate, this tray did not differ from the ones with 128 cells, in this experiment (Tables 4 and 5). Evaluating the use of trays with the same cells volume, in the formation of tomato seedlings, cv Santa Clara 5800, RODRIGUES et al. (2010) verified that the trays with 72 cells were more viable, this conclusion is similar to the presented here.

In the interactions between environment and substrates, as well as in the containers and substrates, the seedlings cultivated in vermiculite were larger and with higher phytomass, in the different environments and containers. The stem diameter, the aerial dry phytomass and total phytomass, in the 200 cells tray, did not differ from the seedlings cultivated in Plantmax ${ }^{\circledR}$ (Table 4). The vermiculite properties, as root system conditioner, were also showed by NEGREIROS et al. (2004) and COSTA et al. (2009 b, c), because this substrate has great capacity of aeration and water retention.

The tomato seedlings in the screenhouse $\left(\right.$ Sombrite $^{\circledR}$ and Aluminet ${ }^{\circledR}$ ) presented better performance (Table 3), according to the observed by COSTA et al. (2009b) in passion fruit, when they verified that the monofilament screen, with 50\% shading, promoted larger plants, than in the greenhouse. Even though the greenhouse had not presented differences in temperature and relative humidity (Table 1), in relation to the screenhouses, in the collect time, it promoted higher greenhouse effect/warming, in function of the LDPF. It caused smaller seedlings development, because in the sunset and evening, it could be storing more energy and promoting higher temperatures.

In this way, in the greenhouse, might have happened higher heating of the substrates and lower seedlings development. Besides, the screen environments provided the entrance of rainwater, what accelerated the organic matter degradation and provided larger quantity of nutrients for the seedlings.

The volume of substrate in the cells interferes in the formed seedling quality and depends on the type of used substrate. The vermiculite evidenced that the higher is the volume the better are the seedlings, with better size and vigor (Tables 4 and 5), agreeing with the results of leafy vegetables and tuberous/tuber, that were reported by MARQUES et al. (2003) and TRANI et al. (2009 b, c) for lettuce; ECHER et al. (2007) for beet. RIBEIRO et al. (2005) and COSTA et al. (2009 b, c) observed that the higher volume provides bigger porous space for root growth, as well as greater quantity of nutrients.

The 128 cell tray presented similar results to the 72 cell tray (Tables 4 and 5) regarding height and dry root phytomass content of plants cultivated in soil, also in the aerial dry phytomass and total phytomass in Plantmax ${ }^{\circledR}$ substrates and coconut fiber (Table 4), the Dickson quality index (DQI) of seedlings cultivated in Plantmax ${ }^{\circledR}$, in the greenhouse and in Sombrite ${ }^{\circledR}$, and the seedlings in coconut fiber in Aluminet ${ }^{\circledR}$ (Table 5). For the vermiculite, however, the 72 cells tray was always superior to the 128 one.

For stem diameter of seedlings in coconut fiber (Tables 4 and 5), dry root phytomass in seedlings produced in Plantmax ${ }^{\circledR}$ (Table 5) and in DQI of seedlings of soil substrate and Plantmax ${ }^{\circledR}$ in Aluminet ${ }^{\circledR}$ (Table 5), the 128 cell tray provided higher values than the 72 cell tray. In general, the 72 cell tray produced the best seedlings, but, depending on the substrate, the 128 cell tray also produced vigorous seedlings. 
The coconut fiber presented promising results in tomato seedling production in others Brazilian states (CARRIJO et al., 2002), but in this study, in the three experiments, it produced seedlings with the lowest DQI (Table 5). It was also observed by RAMOS et al. (2008) in tomato seedlings. Possibly, a bad composting of the fiber may have promoted an irregular development of the seedlings. CARRILO et al. (2002) comment that it is necessary 90 days of composting of this material.

\section{CONCLUSIONS}

The best seedlings were formed in the Sombrite ${ }^{\circledR}$ and Aluminet ${ }^{\circledR}$ screens.

The 72 cell tray promoted the best seedlings.

The vermiculite was the best substrate for seedlings development.

The usage of coconut fiber was not appropriate for tomato seedlings growing.

\section{REFERENCES}

BANZATTO, D. A.; KRONKA, S. N. Experimentação agrícola. 4.ed. Jaboticabal: FUNEP, 2006. $237 \mathrm{p}$.

BOLETIM ANUAL 2011. Comercialização anual da CEASA/MS em 2010. Campo Grande: Governo do Estado, 2011. Available in: www.ceasa.ms.gov.br. Accessed in: 15 maio 2011.

CARRIJO, O. A.; LIZ, R. S.; MAKISHIMA, N. Fibra da casca do coco verde como substrato agrícola. Horticultura Brasileira, Brasília, v.20, n.4, p.533-535, 2002.

CARRIJO, O. A.; VIDAL, M. C.; REIS, N. V. B.; SOUZA, R. B.; MAKISHIMA, N. Produtividade do tomateiro em diferentes substratos e modelos de casas de vegetação. Horticultura Brasileira, Brasília, v.22, n.1, p.5-9, 2004.

COSTA, E.; DURANTE, L.G.Y.; NAGEL, P.L.; FERREIRA, C.R.; SANTOS, A. Qualidade de mudas de berinjela submetida a diferentes métodos de produção. Revista Ciência Agronômica, Fortaleza, v.42, n.4, p.1017-1025, 2011.

COSTA, E.; LEAL, P. A. M.; GOMES, V. A.; MACHADO, D.; JARA, M. C. S. Biomassa de mudas de pepinos híbridos conduzidos sob ambientes protegidos. Bragantia, Campinas, v.69, n.2, p.381-386, 2010.

COSTA E.; RODRIGUES E. T.; ALVES V. B.; SANTOS, L. C. R.; VIEIRA L. C. R. Efeitos da ambiência, recipientes e substratos no desenvolvimento de mudas de maracujazeiro-amarelo em Aquidauana - MS. Revista Brasileira de Fruticultura, Jaboticabal, v.31, n.1, p.236-244, 2009 b.

COSTA E.; SANTOS, L. C. R.; VIEIRA L. C. Produção de mudas de mamoeiro utilizando diferentes substratos, ambientes de cultivo e recipientes. Engenharia Agrícola, Jaboticabal, v.29, n.4, p.528-537, out./dez. 2009 c.

COSTA, E.; VIEIRA, L.C.R.; RODRIGUES, E. T.; MACHADO, D.; BRAGA, A. B. P.; GOMES, V. A. Ambientes, recipientes e substratos na formação de mudas de pepino híbrido. Agrarian, Dourados, v.2, n.4, p.95-116, 2009 a.

CUNHA, R. L.; SOUZA, C. A. S.; ANDRADE NETO, A.; MELO, B.; CORRÊA, J. F. Avaliação de substratos e tamanhos de recipientes na formação de mudas de cafeeiros (Coffea arabica L.) em tubetes. Ciência e Agrotecnologia, Lavras, v.26, n.1, p.7-12, jan./fev. 2002.

ECHER, M. M.; GUIMARÃES, V. F.; ARANDA, A. N.; BORTOLAZZO, E. D.; BRAGA, J. S. Avaliação de mudas de beterraba em função do substrato e do tipo de bandeja. Semina: Ciências Agrárias, Londrina, v.28, n.1, p.45-50, 2007.

FERREIRA, D. F. SISVAR - Sistema de análise de variância. Versão 5.3. Lavras: UFLA, 2010. 
FONTES, P. C. R.; LOURES, J. L.; GALVÃO, J. C.; CARDOSO, A. A.; MANTOVANI, E. C. Produção e qualidade do tomate produzido em substrato, no campo e em ambiente protegido. Horticultura Brasileira, Brasília, v.22, n.3, p.614-619, jul.-set. 2004.

IBGE. Produção agrícola municipal 2009. Rio de Janeiro: IBGE, 2010. (Lavoura Temporária, 2009) .Available in: http://www.ibge.gov.br/cidadesat/link.php?uf=ro. Accessed in: 14 jun. 2011.

LUZ, J. M. Q.; BELLODI, A. L.; MARTINS S. T.; DINIZ, K. A.; LANA, R. G. Q. Composto orgânico de lixo urbano e vermiculita como substrato para a produção de mudas e alface, tomate e couve-flor. Bioscience Journal, Uberlândia, v.20, n.1, p.67-74, jan./abr. 2004.

MARQUES, P. A. A.; BALDOTTO, P. V.; SANTOS, A. C. P.; OLIVEIRA L. Qualidade de mudas de alface formadas em bandejas de isopor com diferentes números de células. Horticultura Brasileira, Brasília, v.21, n.4, p.649-651, 2003.

NEGREIROS, J. R. S.; ÁLVARES, V. S.; BRAGA, L. R.; BRUCKNER, C. H. Diferentes substratos na formação de mudas de maracujazeiro-amarelo. Revista Ceres, Viçosa, v.51, n.294, p.243-249, 2004.

RAMOS, S. J.; GUILHERME, D. O.; CALDEIRA JUNIOR, C. F.; SAMPAIO, R. A.; COSTA, C. A.; FERNANDES, L. A. Tomato seedling production in substrate containing coconut fiber and mushroom culture waste. Agrária, Recife, v.3, n.3, p.237-241, 2008.

RIBEIRO, M. C. C.; MORAIS, M. J. A.; SOUSA, A. H.; LINHARES, P. C. F.; BARROS JUNIOR, A. P. Produção de mudas de maracujá-amarelo com diferentes substratos e recipientes. Caatinga, Mossoró, v.18, n.3, p.155-158, 2005.

RODRIGUES, E. T.; LEAL, P. A. M.; COSTA, E.; PAULA, T. S.; GOMES, V. A. Produção de mudas de tomateiro em diferentes substratos e recipientes em ambiente protegido. Horticultura Brasileira, Brasília, v.28, n.4, p.483-488, 2010.

TRANI, P. E.; NOVO, M. C. S. S.; CAVALLARO JUNIOR, M. L.; TELLES, L. M. G. Produção de mudas de alface em bandejas e substratos comerciais. Horticultura Brasileira, Brasília, v.22, n.2, p.290-294, 2004.

VALENTE, B. S.; XAVIER, E.G.; MORSELLI, T. B. G. A.; JAHNKE, D. S.; BRUM JÚNIOR, B. S.; CABRERA, B. R.; MORAES, P. O.; LOPES, D. N. Fatores que afetam o desenvolvimento da compostagem de resíduos orgânicos. Archivos de Zootecnia, Córdoba, v.58, p.59-85, 2009. 